\title{
Urbanization, Poverty and Culture in the Spatial Patterns of the HIV/AIDS Epidemic in Kenya
}

\author{
Moses Murimi NGIGI*
}

\begin{abstract}
With 1.3 million people infected and 150,000 deaths in 2003, the HIV/AIDS epidemic continues to greatly impact on the Kenyan society. Sentinel surveillance data since 1990 display a regionally-varying epidemic which suggests disparity in the transmission of HIV/AIDS and in the factors influencing its spatial diffusion and intensity across the country. At the national level, the epidemic has been higher among the urban residents. However, provincially disaggregated prevalence does not show correlation with the percentage population that is urban. In spite of this, circular migration as migrants maintain link with their rural homes could be influencing constant diffusion between the rural and urban areas. High prevalence levels in Nyanza province, which has high poverty incidence, suggest the role of poverty in the spread of the epidemic. However, low prevalence in North Eastern province, which has equally-high poverty incidence, indicates that there is more than poverty in the spatial diffusion dynamics of the epidemic. Positively-strong correlation with the Nilotic ethnic group and negative correlation with the Central Bantu, the Western Hamitic, and the Eastern Hamitic suggest the influence of cultural practices in the spatial patterns of the HIV/AIDS epidemic. An expansive surveillance system at lower administrative level would provide more information to explore further the factors influencing the spatial patterns for better mitigation intervention of the epidemic in Kenya.
\end{abstract}

Key words : HIV/AIDS, epidemic, urbanization, poverty, culture, Kenya

\section{Introduction}

Two and a half decades have passed since the initial recognition and eventual definition of the acquired immune deficiency syndrome (AIDS). Over 25 million people have died since the start of the HIV/AIDS epidemic, and an estimated 39.6 million people were living with HIV at the end of 2006 . Globally, the epidemic has displayed very diverse spatial patterns, with Sub-Saharan Africa still the most affected region. According to the Joint United Nations Programme on AIDS
(UNAIDS), 63\% (24.7 million) of the all the people living with HIV live in Sub-Saharan Africa despite the region housing only just over a tenth of the world population. The spatial disparity of the epidemic is evident further within the region with the southern African sub-region showing the highest prevalence rates (proportion of population infected with HIV), after the eastern Africa had its peak in the late 1990s (UNAIDS, 2006).

Various factors have influenced the global HIV/AIDS spatial patterns. These factors include urbanization (Dyson, 2003; Zulu et

\footnotetext{
* Graduate School of Life and Environmental Sciences, University of Tsukuba
} 
al., 2004), geographical mobility (McCoy et al., 1996), poverty (Whiteside, 2002; AgyeiMensah, 2006), and cultural practices (Van de Perre, 1995; Akeroyd, 2004), to mention just but a few. High-risk behaviour among the drug users and homosexuals in the urban areas coupled with high geographical mobility is cited as a strong factor in the spatial diffusion of the epidemic in the urban hierarchy of developed countries (McCoy et al., 1996). Rural-to-urban and international migration have also played a role in the diffusion of the epidemic in the eastern, southern, as well across some West African states (Oppong, 1998; Oppong and Agyei-Mensah, 2004; Kalipeni et al., 2004). Cultural practices linked to sexuality such as male circumcision or the lack of it have influenced the spread of the HIV/AIDS in certain communities, especially in Africa (Akeroyd, 2004). Though cross-sectional studies in Africa have shown the effects of these factors, efforts in understanding their influence in the resulting HIV/AIDS spatial pattern are few.

The objective of this paper is to explore the spatial patterns of the HIV/AIDS epidemic in Kenya against the backdrop of the socio-economic and socio-demographic characteristic of the country. Using surveillance data acquired from the National AIDS and STD Control Programme (NASCOP), the paper explores the spatial pattern of the HIV/AIDS epidemic at the provincial administrative level. The data are HIV prevalence on pregnant women attending selected antenatal clinics (ANC). Like most of the countries in Sub-Saharan Africa, ANC sites are the only data sources that have tracked the HIV/AIDS epidemic for a period; national as well as regional AIDS estimates have also been obtained mainly from the ANC data.

Although testing for HIV in the general population was included in a country-wide demographic and health survey in 2003, this data source is not adequate for the HIV/AIDS epidemic diffusion analysis because previous surveys (before 2003) did not include HIV testing. In addition, there has not been any other survey conducted since 2003; trend analysis needs data collected over a considerable period. ANC sites data, though criticised on its spatial coverage, provided the timetrend necessary for exploring the factors that may be influencing the spatial patterns of the HIV/AIDS epidemic.

\section{The Study Area, Kenya}

Kenya is located in the eastern part of Africa. It shares border with Uganda in the west, Sudan and Ethiopia in the north, Tanzania on the south, Somalia in the east and the Indian Ocean in the south-east (Fig. 1). Administratively, it has eight provinces namely Nairobi, Central, Eastern, North Eastern, Coast, Rift Valley, Western and Nyanza. Nairobi province, located almost in the central part of the country, is the economic, administrative, and social capital of Kenya. It is a cosmopolitan province with a representation of almost all of the country's ethnic communities. Nairobi has also been the main destination for migrants in Kenya. According to the 1999 population census, nearly $70 \%$ of the residents of Nairobi were in-migrants. Moreover, $17 \%$ of the residents had migrated into the province within the previous year.

Neighbouring Nairobi to the north is the Central province. Central province is mainly an agricultural region, with subsistence farming as the major economic activity. Commercial cultivation of tea and coffee in this area is also an important economic activity. A few industries, commercial farms, and closeness to the city make the Central province also attractive to migrants from the other provinces.

The Rift Valley is the largest of the provinces, straddling the country from the border with Ethiopia in the North to the Tanzanian border in the south (Fig. 1). The province is very diverse, as it is composed of a landscape that varies from savannah in the south, cool and agriculturally productive highlands in the middle, to dry and bare semi-desert in the north. 


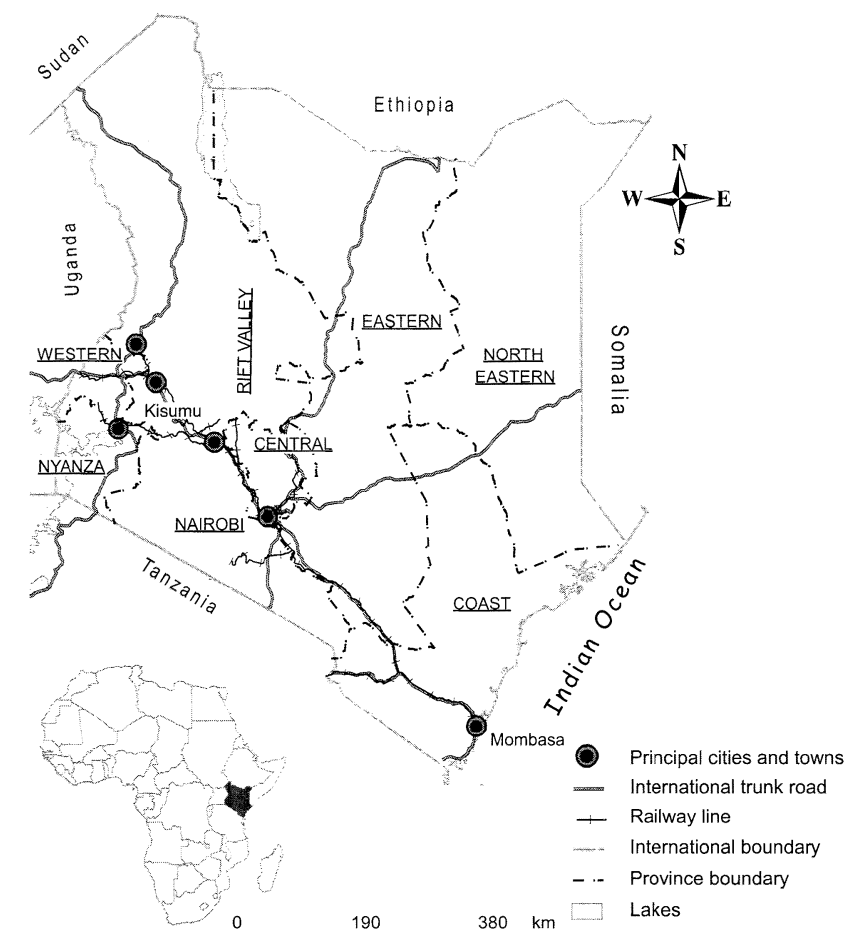

Fig. 1 Location of Kenya. Map shows the neighbouring countries and administrative provinces of Kenya.

The Eastern province, the second largest after the Rift Valley, is also climatically as diverse as the Rift Valley, with its most productive area close to the Central province. The main economic activity is also subsistence and cash crop farming. In the drier regions in the north, pastoralism is the main economic activity.

Nyanza and Western provinces lie in the west of the country. Nyanza province, borders Lake Victoria, making fishery one of the major economic activities. Farming is also a significant economic activity in this province. Kisumu, the capital of Nyanza province, (Fig. 1 ) is one of the principal urban centres in Kenya. The Western province is the main link of Kenya with the neighbouring countries as the international trunk road leaves the country through this province. The main economic activity of the province is agriculture. Western and Nyanza provinces are one of the major sources of migrants to the capital city, Nairobi.

The Coast province, lying to the southeast of Kenya, is the gateway to East Africa, through the port city of Mombasa. The province is also attractive to many migrants and workers as it provides a unique economic activity in tourism. The North Eastern province, neighbouring Somalia (Fig. 1) is mainly dry. Due to unreliable rainfall and harsh climatic conditions, the main economic activity is pastoralism. The province has also very low economic exchange with the other provinces.

Kenya has a population of about 34 million (2006 estimate: Kenya, Central Bureau of Statistics, 2002) distributed among the eight provinces at varying density levels. Nyanza and Western provinces in the west, central parts of Rift Valley province, Central province, part of Eastern province, part of the Coast province and Nairobi are characterised by 


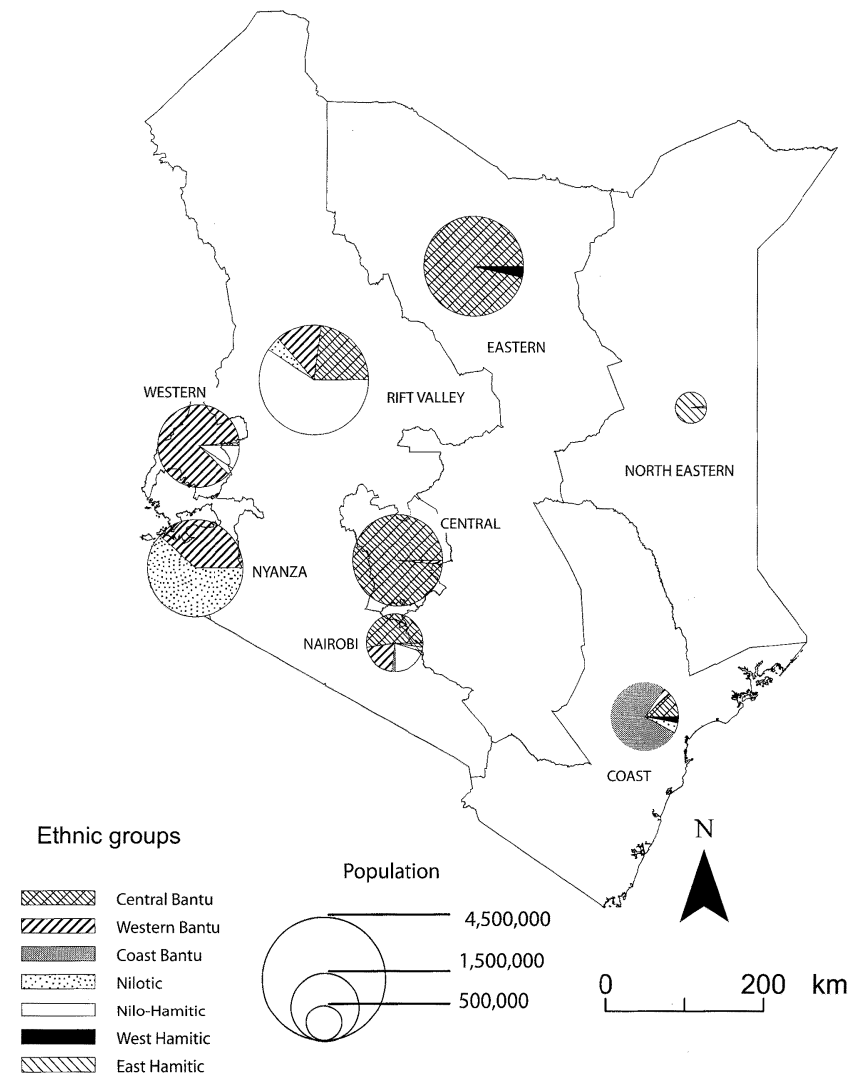

Fig. 2 Distribution of the major ethnic classifications by province. Source: Compiled from the 1989 population census.

high population density. These regions are characterised by adequate and frequent rainfall and arable land suitable for agricultural activities, making it conducive for population settlements. The rest of the country is dry savannah and semi-arid, characterised by low population density.

Kenya's population is multi-ethnic. The $98 \%$ of Kenya's population who are Africans are composed of more than 40 ethnic communities. Based on their anthropological origins and historical settlement patterns, the ethnic communities fall into seven groups, namely the Central Bantu, Western Bantu, Coast Bantu, Nilotic, Nilo-Hamitic, Eastern Hamitic and Western Hamitic. The 1989 census, which included Kenya's ethnic composition, indicates that though Kenya is multi-ethnic, regional ethnic concentration characterise the population settlements among the provinces (Fig. 2). The Central Bantu are mainly to be found in Central, Eastern, and parts of the Rift Valley province; the Western Bantu dominate in Western province, while the Eastern Hamitic is the dominant group in the North Eastern province. The Coast province is occupied mainly by the Coast Bantu, while Nyanza Province is composed of both the Nilotic and the Western Bantu. Rift Valley, Nairobi, and to some extent the Coast province, show higher levels of ethnic mixing. Nairobi is composed of three major groups, the Central Bantu, the Western Bantu, and the Nilotic, while the Rift Valley has the Nilo-Hamitic, the Central Bantu, and the Western Bantu.

In terms of residential characteristic of the 

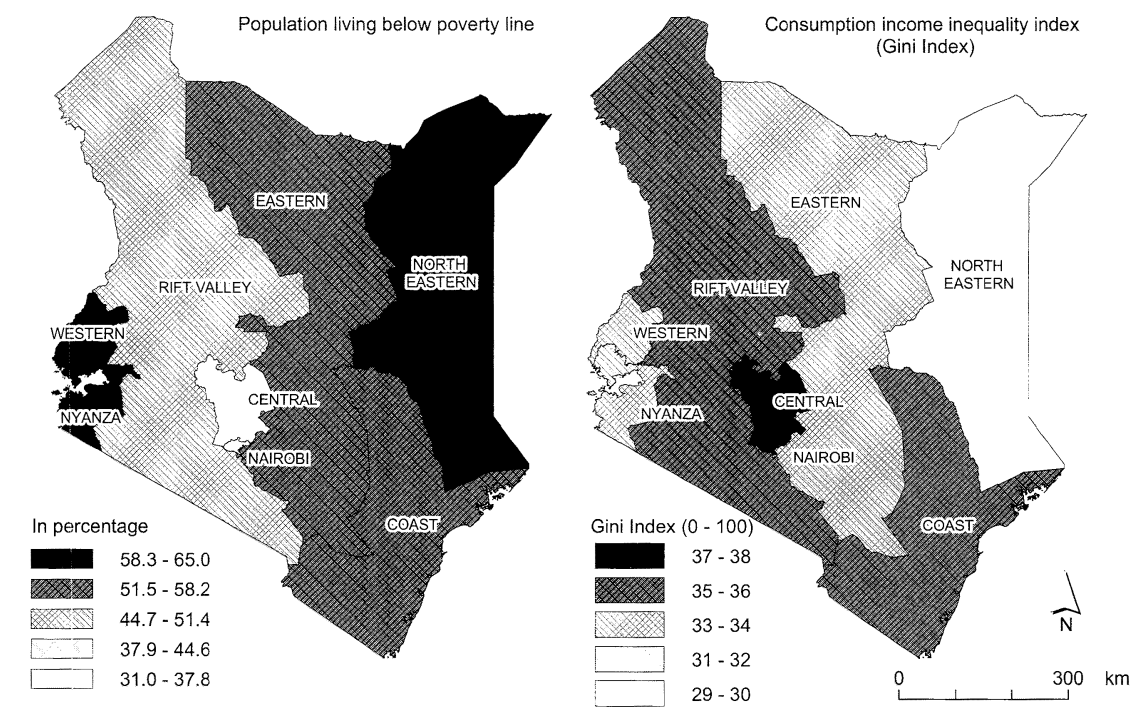

Fig. 3 Poverty levels in Kenya, 1999.

Source: Based on data from Kenya, Central Bureau of Statistics (2003) and Kenya, Central Bureau of Statistics (2005).

population, most of Kenya's population resides in the rural areas. In the 1999 population census, only $19 \%$ of Kenya's population lived in the urban areas, of which $38 \%$ resided in Nairobi (Kenya, Central Bureau of Statistics, 2004). Among the provinces, Nairobi is the most urbanised, with all its population classified as urban. Coast province follows with $37 \%$; the Western province has the least with $8 \%$ of its population living in urban areas. Migration statistics show that the composition of Nairobi's population has benefited greatly from migrants from other provinces, especially from the neighbouring Central and Eastern provinces, and from the distant Nyanza and Western provinces.

Economically, the characteristic of Kenya at the provincial level could best be depicted using poverty incidence and inequality measures for the year 1999, which were estimated and published in 2003 and 2005 by the Kenya Central Bureau of Statistics. These measures define the percentage of population living below the consumption poverty line (poverty incidence) and the dispersion of income used for basic consumption among a population living within a defined area of consideration, respectively.

In Kenya, the poverty line, quantified as the amount of money that one needs to afford food that is equivalent to 2,250 calories per day, converts to Kenya Shillings 1,239 and 2,648 (about US\$ 17 and US\$34) per month for the rural and urban areas, respectively. The Gini index, scale of zero to one hundred (zero meaning most equitable distribution and one hundred the most inequitable), addresses not just those below poverty line but the consumption income of the entire population (Kenya, Central Bureau of Statistics, 2005, 2003).

Fig. 3 shows the spatial characteristic of poverty in Kenya, aggregated at the provincial level. Nyanza province leads in poverty with $65 \%$ of its population below the poverty line, followed by North Eastern and Western with $64 \%$ and $61 \%$, respectively. Nairobi and Central provinces have the least levels of poverty incidence, with $48 \%$ and $31 \%$ respectively. In contrast, the Gini index indicates that though Nairobi and Central provinces have the lowest poverty incidences, they have the most inequitable consumption income distribution among 


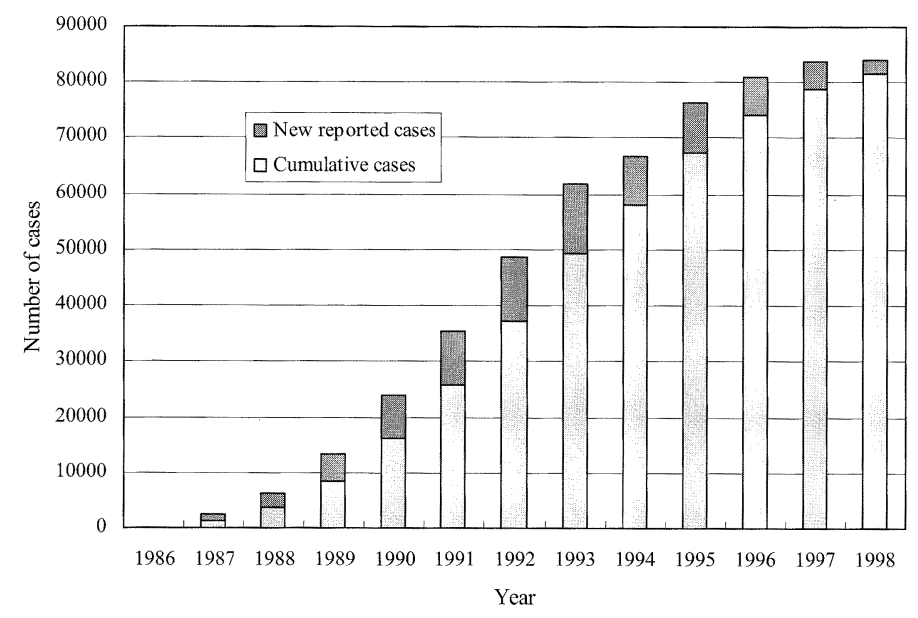

Fig. 4 Reported AIDS cases in Kenya, 1986-1998. Source: UNAIDS/WHO/UNICEF (2002).

the provinces.

\section{Overview on HIV/AIDS in Kenya}

At the end of 2003, Kenya had an estimated 1,300,000 people with HIV/AIDS (NASCOP/ Ministry of Health, 2005). The entry of the epidemic was recognized in Kenya when in 1984 the first case of AIDS was diagnosed in a Ugandan citizen living in Nairobi. A study soon after revealed that HIV had extensively spread in the prostitute population in Nairobi; sexual exposure to men from Central Africa was the significant contributing factor to the infections (Kreiss et al., 1986). The reported cases of AIDS increased dramatically, rising to over 80,000 by 1998 (Fig. 4). The almost equal number of reported female and male cases suggested heterosexual contact to be the main mode of transmission.

Owing to the fact that heterosexual contact was the main mode of HIV transmission, and the realization that the reported AIDS cases represented infections that had taken place some years before, systematic HIV infection surveillance on ANC was inaugurated in 1990. National HIV prevalence estimates from this surveillance system indicate that the HIV/AIDS epidemic in Kenya peaked in the late $1990 \mathrm{~s}$, from when it started a gradual but steady decline (Fig. 5). The decline could have been a product of increased deaths due to AIDS and/or the reduction in transmission rates following relentless mitigation effort that had reached the peak in 1999 when the then president of Kenya declared HIV/AIDS to be a national disaster.

Despite the national decline, provincial estimates indicated that disparity in the trends of the epidemic still varied a lot. Fig. 6 shows a comparison of estimated provincial HIV prevalence of 2004 from ANC sites and from the demographic and health survey in 2003. The similarity in the trends indicates that prevalence rates from surveillance on pregnant women were a good representation of the regional trends. This similarity implies that the ANC data is useful in exploring the spatial patterns and factors that have influenced the provincial differences in the progression of the epidemic.

\section{Data and Methods}

The National AIDS and Sexually transmitted diseases Control Programme (NASCOP), in the Kenya Ministry of Health, started the country-wide sentinel surveillance for HIV infections at 13 ANC sites. In 1995, number of sites was 22 , reaching 44 by 2004 . Each 


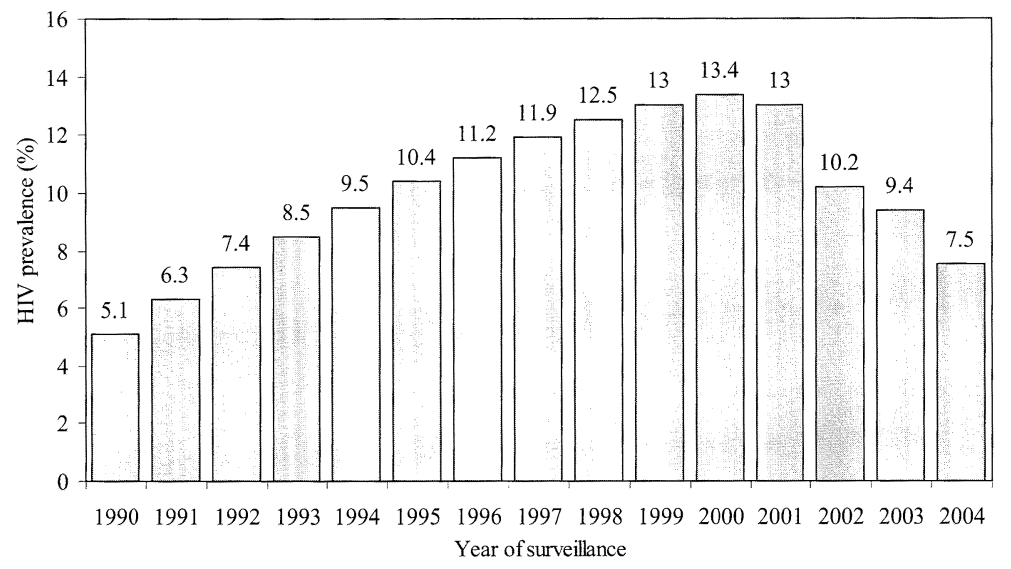

Fig. 5 Estimated national HIV prevalence from sentinel surveillance on pregnant women at selected antenatal clinics, 1990 to 2004.

Source: NASCOP/Ministry of Health. Sentinel Surveillance Report of 2004.

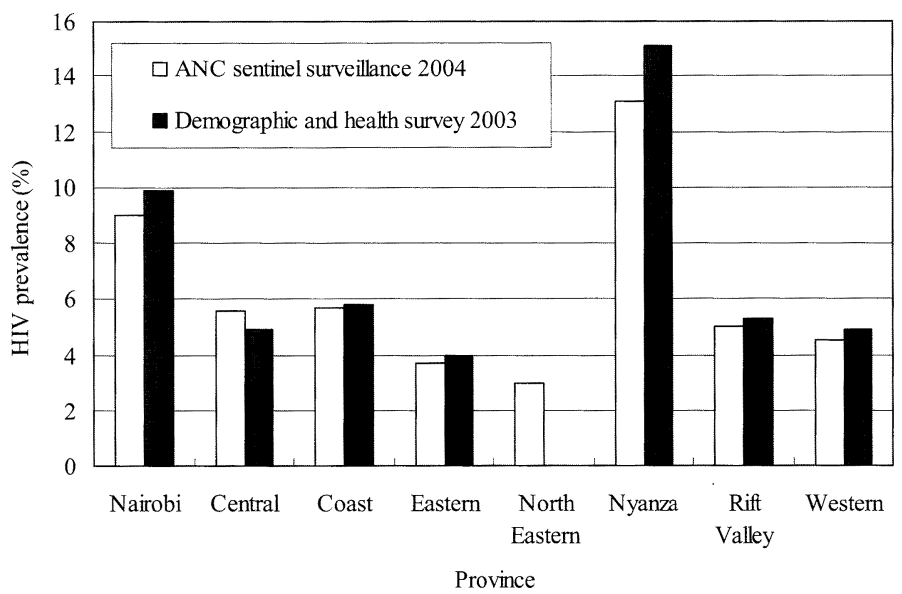

Fig. 6 Comparison of estimated HIV prevalence from ANC surveillance and from population health survey.

Source: Kenya, National AIDS Control Council (2005); NASCOP/ Ministry of Health (2005).

of the eight administrative provinces of Kenya has at least one surveillance site, with more sites located in the higher-populated provinces.

The ANC prevalence data were examined for completeness and consistency; 23 sites that had data as early as 1996 and earlier were selected. Some of the sites had missing prevalence values for one or two years; these values were estimated by linear interpolation between the closest available years with data.
The provincial HIV prevalence was then calculated by averaging the prevalence data of the ANC sites within their borders.

The demographic and socio-economic data used in this research were sourced from publications from the Central Bureau of Statistics of Kenya. The selected census variables were: urban population in each province, poverty incidence (percentage population living below poverty line) and income distribution inequal- 
ity index, ethnic communities, and migration data for each province. The poverty and income inequality index data were for the year 1999, while ethnic group data were taken from the 1989 population census. The other data were available for both 1989 and 1999.

In order to describe the HIV trends, polynomial curves that best fitted the trend of the provincial prevalence data were plotted for each province. Values from the polynomial curves were then used to map the spatial progression of the HIV with the aid of a geographical information system (GIS). The obtained prevalence values for 1990 and 2000 were then used in bivariate correlation analysis against urban population, migration, and ethnic-grouping variables while bivariate correlation analysis against poverty incidence and the income inequality index was carried out with the $2000 \mathrm{HIV}$ prevalence only.

\section{Analysis}

Nationally aggregated HIV prevalence values indicate that the HIV/AIDS epidemic in Kenya peaked in 2000. However, provincial values reveal that several of the provinces reached their peak prevalence as early as in the early 1990s. The epidemic was already spatially present in all the provinces, but at varying levels, even in 1990(Fig. 7 and Fig. 8). Western and Nyanza provinces in the west of the country, and the Coast province had the highest prevalence rates. Rift Valley and Nairobi provinces showed moderate prevalence of $5 \%$ and 6\%, while the North Eastern, Eastern and the Central provinces portrayed the lowest prevalence levels.

The higher prevalence levels of $10 \%$ and above in Nyanza, Coast and Western provinces, in comparison to the provinces located in the middle of the country suggest an external source of the HIV spatial diffusion process into Kenya. Rapid rise in prevalence rates for both Nairobi and the Rift Valley, and soon after in Central province indicate a high rate of interaction among the provinces.

The epidemic curves in Fig. 7 show the sub-epidemics of the HIV/AIDS in Kenya, with different gradient and peaks. The curves follow typical 'S' epidemic curve, where the rise in prevalence rates indicates the spread of the HIV through the susceptible population. As the slope of the curves suggest, Central province, Nairobi, and the Rift Valley experienced rapid rise in the $\mathrm{HIV}$ prevalence levels in the early years of the surveillance.

While the Rift Valley province attained its peak prevalence value as early as 1993 , other provinces continued to show increasing prevalence, with the Eastern and Nyanza provinces reaching their maximum values at the latest, in 1998 and 2000, respectively. The shapes of the trend curves in Fig. 7 show that only North Eastern province had had the lowest infection levels through out the surveillance period. The different prevalence levels at the start of surveillance, the variation in the rise and peaking levels, and the year when prevalence levels started declining suggest the influence of different factors in the provincial spread of the HIV/AIDS epidemic.

Several factors have been attributed to influencing the spatial diffusion as well as the regional disparities of the HIV/AIDS epidemic in Sub-Saharan Africa. These factors include cultural practices surrounding sexuality among certain ethnic communities, migration, and vulnerability, among many other interrelated factors (Oppong, 1998; Brockerhoff and Biddlecom, 1999; Akeroyd, 2004). For example, migration and urbanization are interrelated as most of the migration in Africa is between the rural and urban areas. Despite the knowledge of the influences of these factors, many are not included in national-level surveillance systems.

\section{1) HIV/AIDS, urbanization and migra- tion}

A wide range of surveillance data show higher prevalence levels for urban areas, despite the fact that urban residents tend to show greater awareness of AIDS and ways of preventing HIV infection. In 2003, it was estimated that $6.7 \%$ of Kenyan adults were 


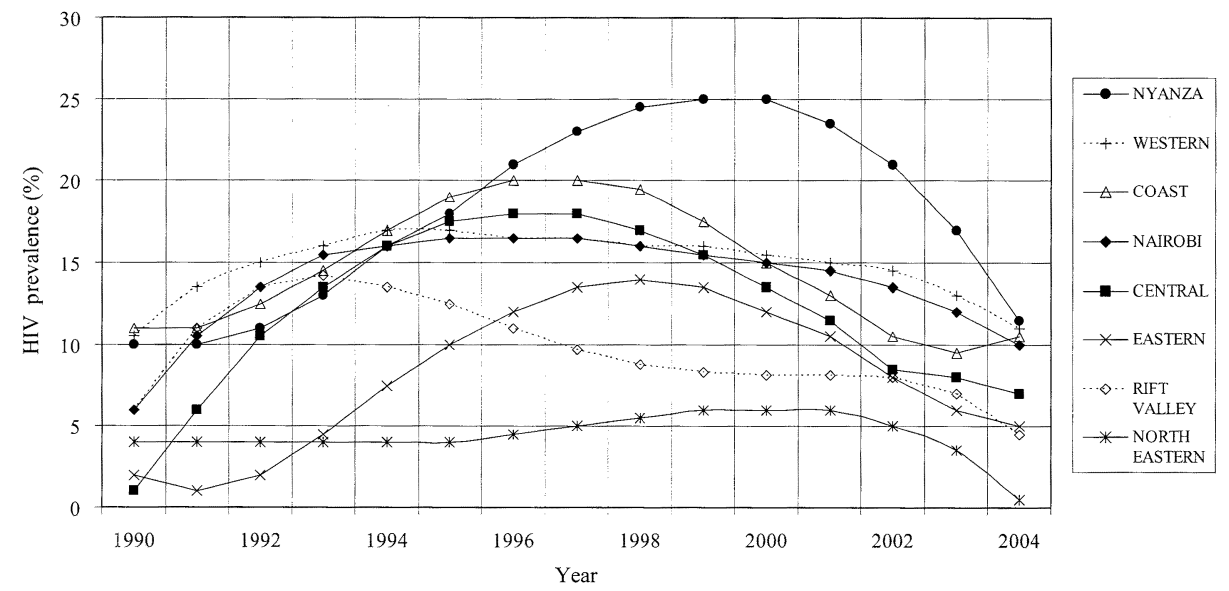

Fig. 7 Provincial HIV prevalence trends, 1990-2004.

Source: Based on antenatal clinic surveillance data from NASCOP.
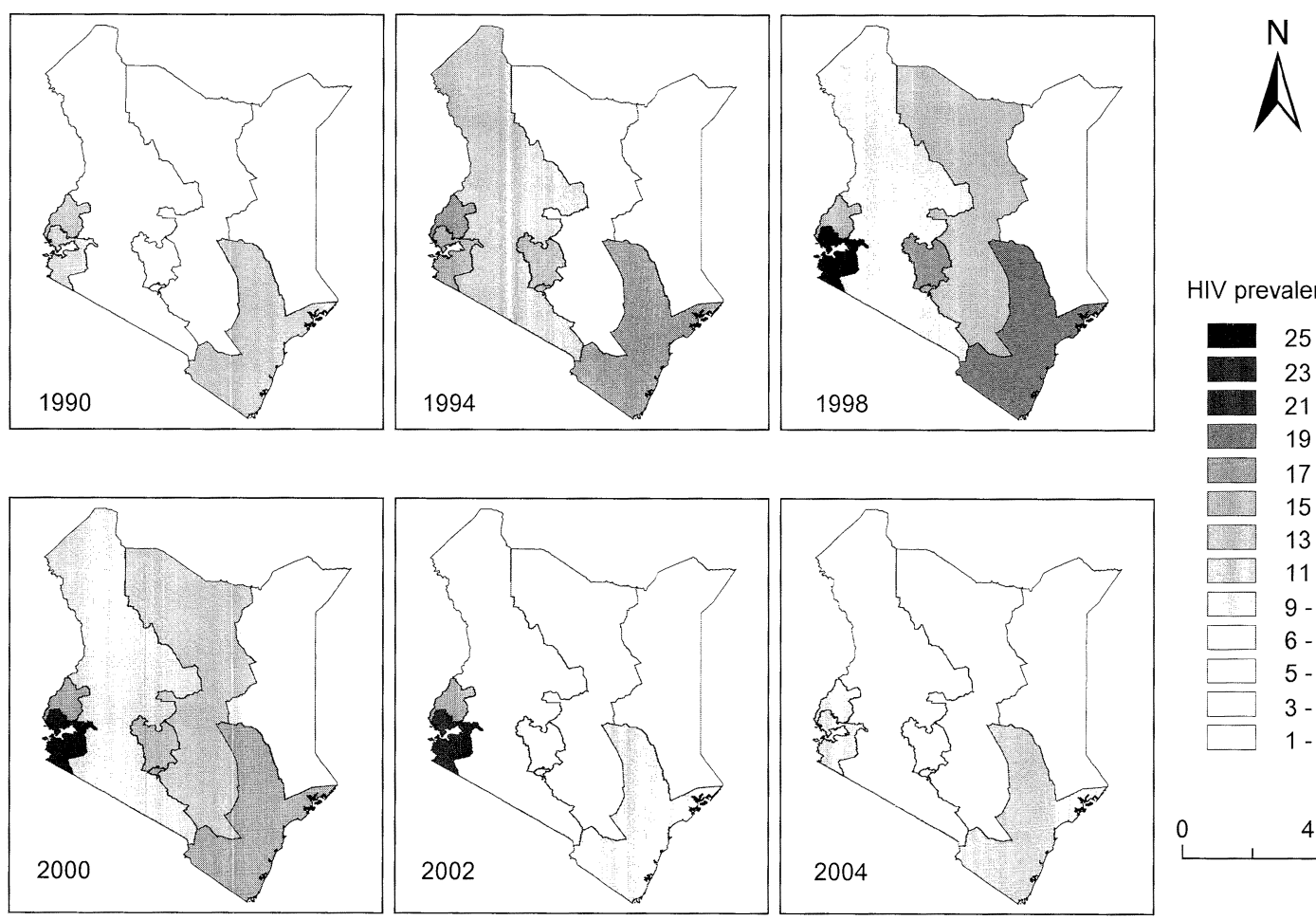

HIV prevalence(\%)

$25-26$

$23-24$

$21-22$

$21-22$
$19-20$

$17-18$
$15-16$

$15-16$
$13-14$

प11-12

$9-10$

$6-8$

$5-6$

$3-4$

$1-2$

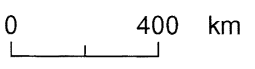

Fig. 8 Spatial trend of the HIV/AIDS epidemic in Kenya, 1990-2004.

HIV positive (NASCOP/Ministry of Health, 2005). The HIV prevalence rate for the urban residents was $10 \%$ while that of the rural was $5.6 \%$, an almost double in difference.
Despite the observation that HIV prevalence is higher in the urban areas, provincial differences in prevalence could not be explained by this factor because the bivariate correlation 
Table 1 Correlation matrix of HIV prevalence in 1990 and 2000 against provincial urban population and percentage of in-migrants.

\begin{tabular}{|c|c|c|c|c|c|c|}
\hline & $\begin{array}{c}\text { HIV } \\
\text { prevalence } \\
1990\end{array}$ & $\begin{array}{c}\text { HIV } \\
\text { prevalence } \\
2000\end{array}$ & $\begin{array}{c}\text { Percentage } \\
\text { urban population } \\
1989\end{array}$ & $\begin{array}{c}\text { Percentage } \\
\text { urban population } \\
1999\end{array}$ & $\begin{array}{c}\text { Percentage } \\
\text { in-migrants } \\
1989\end{array}$ & $\begin{array}{c}\text { Percentage } \\
\text { in-migrants } \\
1999\end{array}$ \\
\hline $\begin{array}{l}\text { HIV prevalence } \\
1990\end{array}$ & 1 & & & & & \\
\hline $\begin{array}{l}\text { HIV prevalence } \\
2000\end{array}$ & $\begin{array}{c}0.534 \\
(0.086)\end{array}$ & 1 & & & & \\
\hline $\begin{array}{l}\text { Percentage urban } \\
\text { population } 1989\end{array}$ & $\begin{array}{c}0.038 \\
(0.464)\end{array}$ & $\begin{array}{c}0.002 \\
(0.498)\end{array}$ & 1 & & & \\
\hline $\begin{array}{l}\text { Percentage urban } \\
\text { population } 1999\end{array}$ & $\begin{array}{c}0.101 \\
(0.406)\end{array}$ & $\begin{array}{c}0.074 \\
(0.431)\end{array}$ & $\begin{array}{c}0.990 \\
(0.000)\end{array}$ & 1 & & \\
\hline $\begin{array}{l}\text { Percentage } \\
\text { in-migrants } 1989\end{array}$ & $\begin{array}{c}0.030 \\
(0.472)\end{array}$ & $\begin{array}{c}0.029 \\
(0.473)\end{array}$ & $\begin{array}{c}0.958 \\
(0.000)\end{array}$ & $\begin{array}{c}0.969 \\
(0.969)\end{array}$ & 1 & \\
\hline $\begin{array}{l}\text { Percentage } \\
\text { in-migrants } 1999\end{array}$ & $\begin{array}{c}0.018 \\
(0.483)\end{array}$ & $\begin{array}{c}0.074 \\
(0.431)\end{array}$ & $\begin{array}{c}0.955 \\
(0.000)\end{array}$ & $\begin{array}{c}0.970 \\
(0.000)\end{array}$ & $\begin{array}{c}0.997 \\
(0.000)\end{array}$ & 1 \\
\hline
\end{tabular}

Significance levels in the parentheses.

between HIV prevalence in both 1990 and 2000 against provincial percentage of population that was urban did not reveal any significant correlation (Table 1). The lack of a significant correlation could be explained from the fact that in the early 1990s the epidemic was more severe in provinces with lower urban population, an indication of a possible rural origin of the epidemic. By 1999, the epidemic had already penetrated into the rural areas, and decline had started in the major urban areas.

Likewise, the correlation between HIV prevalence and migration did not also show any correlation. However, as Table 1 shows, the percentage of in-migrants to each province in both 1989 and 1999 censuses strongly correlate with the percentage of the population that is urban. This could be due to the fact that rural-to-urban migration dominates migration in Kenya. The fact that HIV prevalence has been higher in provinces that are less urban conceals the relationship and role of urbanization in the spread of HIV. Nevertheless, as migrants to the urban areas always maintain link with the rural areas, the spread of HIV between the urban and rural areas and vice versa is still likely. Frequent visits between urban and rural areas, or circular migration, a common phenomenon in Kenya, might maintain constant rates of infection at both rural and urban ends of the migration chain (Ngigi, 2007). Many migrants to the urban areas such as in the city of Nairobi live also in abject poverty. The social environment, and the cost of living in the city, propels the migrants, especially women, to engage in risky sexual engagements for basic survival (Zulu et al., 2004).

\section{2) HIV/AIDS and culture}

Some similarities do exist in some cultural practices among the ethnic communities that constitute the seven anthropologically-classified ethnic groups in Kenya. For example, most of the Bantu practice male circumcision, while the Nilotic do not. Among the Nilotic, wife inheritance is a common cultural custom. A widow gets 'inherited' after the death of her husband, and should fulfil some cleansing rites as required by the community. The inheritance involves having sex with a man who is also supposed to take care of the widow. Traditionally, the brothers of the deceased had to inherit the widows to ensure 
Table 2 Bivariate correlation between HIV prevalence in 1990 and 2000 against provincial ethnic composition.

\begin{tabular}{|c|c|c|c|c|c|c|c|}
\hline & $\begin{array}{c}\text { Central } \\
\text { Bantu }\end{array}$ & $\begin{array}{c}\text { Western } \\
\text { Bantu }\end{array}$ & $\begin{array}{c}\text { Coastal } \\
\text { Bantu }\end{array}$ & Nilotic & Nilo-Hamitic & $\begin{array}{l}\text { Western } \\
\text { Hamitic }\end{array}$ & $\begin{array}{l}\text { Eastern } \\
\text { Hamitic }\end{array}$ \\
\hline HIV prevalence, 1990 & $\begin{array}{r}-0.801 \\
(0.008)\end{array}$ & $\begin{array}{c}0.617 \\
(0.052)\end{array}$ & $\begin{array}{c}0.488 \\
(0.110)\end{array}$ & $\begin{array}{c}0.430 \\
(0.144)\end{array}$ & $\begin{array}{c}0.028 \\
(0.474)\end{array}$ & $\begin{array}{r}-0.097 \\
(0.410)\end{array}$ & $\begin{array}{r}-0.242 \\
(0.282)\end{array}$ \\
\hline HIV prevalence, 2000 & $\begin{array}{c}-0.154 \\
(0.358)\end{array}$ & $\begin{array}{c}0.441 \\
(0.137)\end{array}$ & $\begin{array}{c}0.088 \\
(0.418)\end{array}$ & $\begin{array}{c}0.829 \\
(0.005)\end{array}$ & $\begin{array}{r}-0.387 \\
(0.172)\end{array}$ & $\begin{array}{r}-0.109 \\
(0.399)\end{array}$ & $\begin{array}{r}-0.552 \\
(0.078)\end{array}$ \\
\hline
\end{tabular}

Significance levels in the parentheses.

his property remained within the family circle. In case there was no one ready to inherit the widow, 'professional inheritors' had to perform the customary duty of inheriting the widow. As the culmination of the inheritance involved sex, and in the AIDS era many of the widows were also infected, the infection chain extended to the inheritor, to his wife and eventually to the next inheritor. Refusal to be inherited resulted in losing support from the family, or right to participate in other societal ceremonies such as attending burials of close relatives. Even with full knowledge that a widow was already HIV positive, some inheritors insisted on having sex without condoms (Luginaah et al., 2005).

As Fig. 2 depicted, there is dominance of specific ethnic groups in most of the provinces. The concentration of a people of similar culture may influence the spatial pattern of the epidemic through cultural practices that either reduce or increase the transmission risks of HIV. The Nilotic, mainly composed of the Luo ethnic community, practise wife inheritance. This cultural practice coupled by lack of male circumcision could have played a major role in the high prevalence rates seen in Fig. 7 and Fig. 8.

Table 2 shows the bivariate correlation between HIV prevalence and the ethnic groups in 1990 and 2000. Positive, but not so strong, correlations with the Western Bantu, the Coastal Bantu, and the Nilotic are observed in 1990, while exhibiting a strong negative correlation $(R=-0.801)$ with the Central Bantu. In 2000, a strong and significant correlation $(R=0.829)$ with the Nilotic is in line with the high HIV prevalence in Nyanza province while in other provinces a decline had started. This strong correlation with the Nilotic who form the majority of the population of Nyanza province reaffirms the role of cultural factors in the high prevalence rates seen from the early 1990s. The significant negative correlation with the Central Bantu might not definitely indicate the role of the ethnic group's cultural practices, although the Central Bantu practise male circumcision, a cultural factor said to lower the risk of infection. The relation may simply be highlighting the epidemic's trend since 2000. The Central Bantu are mainly in areas that are close to and in the city of Nairobi; therefore, they have more access to frequent mitigation information.

\section{3) HIV/AIDS and poverty}

The association between poverty and HIV/ AIDS is a subject much debated by scientists and of great concern to governments and donor agencies (Agyei-Mensah, 2006). Poverty is said to be linked to HIV/AIDS in different ways; on the one hand, it is seen as a causative factor of HIV/AIDS in which economically deprived people engage in economic practices such as prostitution that puts them at risk to HIV and AIDS. On the other hand, it is seen as a consequence of HIV/AIDS where the infected use all their resources for treatment and are economically unproductive due to their weak physical conditions.

Mixed results on the links between poverty and HIV/AIDS have been observed. For example, Botswana with the highest per capita income in Sub-Saharan Africa has one of the highest levels of HIV infection (Whiteside, 
(a)

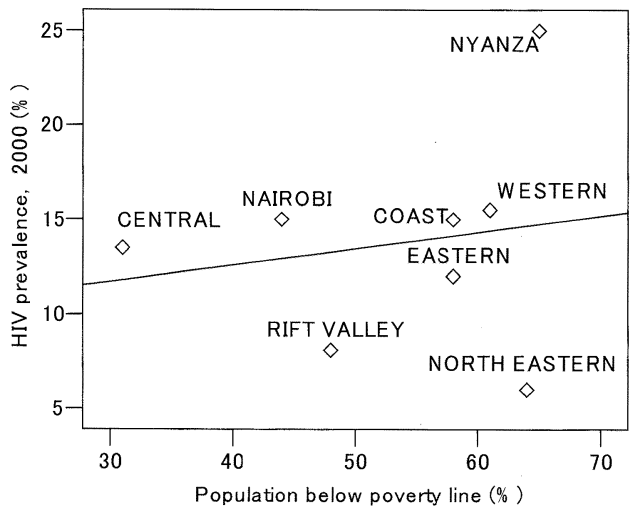

(b)

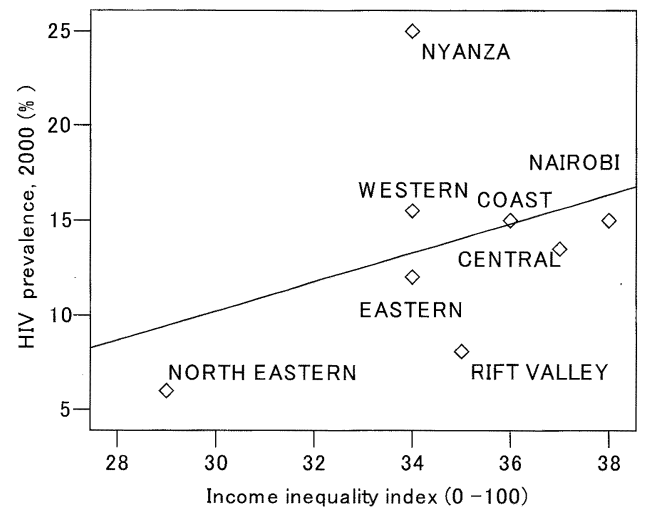

Fig. 9 HIV prevalence in 2000 against (a) population living below consumption poverty line and (b) income inequality index.

Source: Poverty and income distribution are based on Kenya, Central Bureau of Statistics（2003） and Kenya, Central Bureau of Statistics (2005); HIV prevalence data are from the trend curves on Fig. 7.

2002; Agyei-Mensah, 2006). Whiteside (2002) argues that economic growth may cause change that encourages HIV spread as does economic decline and stagnation. Quick economic growth disrupts traditional norms and people cannot adapt to the changes. Economic growth also skews income distribution and changes distribution patterns, but with growth, at least there is potential that people will become better off and there will be resources to fight the disease (Whiteside, 2002). Nevertheless, the links between poverty and HIV/ AIDS amongst different socio-economic groups and geographical regions need to be well understood because nationally aggregated values mask a lot of in-country differences.

Nyanza province, which has the highest poverty incidence, shows the highest HIV prevalence rates. In contrast, North Eastern province with equally high levels of poverty has had very low prevalence rates all through the surveillance period (Fig. 7). A scatter plot between poverty incidence and HIV prevalence does not show strong correlation (Fig. 9). This could be due to the fact that no single factor acts on its own in increasing the HIV/AIDS risks. The environment in which a poor person may get into risky behaviour is governed by other factors such as presence a persons with a higher income who are willing to pay for sex. Both measures of poverty indicate the likelihood of higher HIV infection levels in areas where inequalities in income distribution are high. The scatter diagrams however show the direction of the relationship; higher levels of poverty may lead to higher rates of infection.

In a case study on the spatial characteristic of HIV/AIDS in the city of Nairobi, it was found that there was higher concentration of people living with HIV/AIDS (PLWHA) in regions characterised by higher density of persons living below poverty line. The PLWHA were mainly the low income, and could only afford livelihood in the poor residential areas of the city. Therefore, even though at a macro-scale surveillance data may not show a direct link with poverty, there existed a relationship at the micro-scale, as HIV/AIDS was caused by factors brought about by poverty, and, progression of HIV to AIDS increases poverty in several ways such as increased cost on medication, loss of job, low productivity, and so on.

\section{Conclusion}

This paper has examined the spatial characteristic of the HIV/AIDS epidemic in Kenya at 
the provincial administrative boundary level. The scale of analysis was chosen because the HIV prevalence surveillance data since the early 1990s was only available for few sites, nonetheless several important issues were observed.

The HIV epidemic levelled off in the provinces at different years, with nearly all provinces maintaining constant prevalence levels untill the late 1990s when steady drop was observed in all provinces. The levelling off of the epidemic at different times suggests that factors influencing the spatial diffusion of HIV/ AIDS acted at different rates among the provinces. The analysis of the prevalence against urbanization, ethnic composition, and poverty characteristics did not explicitly identify one single factor that is influencing the provincial patterns of the HIV/AIDS pandemic. Nonetheless, the influence of cultural practices is exemplified by the strong positive correlation of HIV with the Nilotic ethnic group in year 2000. Concentration of specific ethnic groups in the provinces could be a start point in investigating other cultural factors that may be contributing positively in lower prevalence levels. For example, the low prevalence observed in the North Eastern province, and the early peaking and decline in the Rift Valley province, could be due to regionally-based barriers to the diffusion of the epidemic. North Eastern province is characterised by harsh economic and weather conditions. It hardly attracts immigrants and thus could have low rates of diffusion. Islam is the predominant religion in the North Eastern province; the strictness of the religion in matters of maintaining sexual purity is a factor which could be influencing the low rates.

The generalization of a few sentinel surveillance sites to represent the provinces with varying socio-economic characteristics such as the vast Rift Valley and Eastern provinces reduced the possibilities of a robust statistical analysis. However, the sentinel surveillance data is the only available data that can trace the progression of the HIV/AIDS epidemic.
An expansion of the surveillance system to include each administrative district (lower scale than one used in this research) in the country would provide more data which would enable better analysis with more localized sociodemographic and socio-economic characteristics that would offer better solutions for controlling the spread of the epidemic or prevent its reemergence.

\section{Acknowledgements}

I gratefully acknowledge the National AIDS and STD Control Programme (NASCOP)/Ministry of Health of Kenya for the HIV prevalence data, and the Central Bureau of Statistics (of Kenya) for the population census and poverty mapping data. I sincerely thank Prof. Yuji Murayama (University of Tsukuba, Japan) for his support, encouragement and invaluable comments during the writing of the paper, and the anonymous referee(s) for the constructive suggestions.

\section{References}

Agyei-Mensah, S. (2006): Poverty and HIV prevalence in Ghana: A geographical perspective. GeoJournal, 66, 311-324.

Akeroyd, A.V. (2004): Coercion, constraints, and cultural entrapments: A further look at gendered and occupational factors pertinent to the transmission of HIV in Africa. in HIV and AIDS in Africa: Beyond Epidemiology edited by Kalipeni, E., Craddock, S., Oppong, J.R. and Ghosh, J., Blackwell, 89-103.

Brockerhoff, M. and Biddlecom, A.E. (1999): Migration, sexual behaviour, and risk of HIV in Kenya. Int. Migr. Rev., 33, 833-856.

Dyson, T. (2003): HIV/AIDS and urbanization. Popul. Dev. Rev., 29, 427-442.

Kalipeni, E., Craddock, S. and Ghosh, J. (2004): Mapping the AIDS pandemic in Eastern and Southern Africa: A critical overview. in $H I V$ and AIDS in Africa: Beyond Epidemiology edited by Kalipeni, E., Craddock, S., Oppong, J.R. and Ghosh, J., Blackwell, 58-69.

Kenya, Central Bureau of Statistics (2002): Kenya 1999 Population and Housing Census Vol. VII: Analytical Report on Population Projections. Central Bureau of Statistics.

Kenya, Central Bureau of Statistics (2003): Geographic Dimensions of the Well-Being in Kenya. Where are the Poor? From Districts to Locations Vol. I. Central Bureau of Statistics.

Kenya, Central Bureau of Statistics (2004): Kenya 
1999 Population and Housing Census, Volume VI: Analytical Report on Migration and Urbanization. Central Bureau of Statistics.

Kenya, Central Bureau of Statistics (2005): Geographic Dimensions of the Well-Being in Kenya. Who and Where are the Poor? A Constituency Level Profile Vol. II. Central Bureau of Statistics.

Kenya, National AIDS Control Council (2005): Kenya HIV/AIDS Data Booklet. National AIDS Control Council.

Kreiss, J.K., Koech, D., Plummer, F.A. et al. (1986): AIDS virus infection in Nairobi prostitutes: Spread of the epidemic to East Africa. N. Engl. J. Med., 314, 414-418.

Luginaah, I., Elkins, D., Maticka-Tyndale, E. et al., (2005): Challenges of a pandemic: HIV/AIDS related problems affecting Kenyan widows. Soc. Sci. Med., 60, 1219-1228.

McCoy, V.H., Correa, R. and Fritz, E. (1996): HIV diffusion patterns and mobility: Gender differences among drug users. Popul. Res. Policy Rev., 15, 249-264.

National AIDS and STD Control Programme (NASCOP) / Ministry of Health (2005): AIDS in Kenya: Trends, Intervention and Impact. NASCOP.

National AIDS and STD Control Programme (NASCOP) / Ministry of Health (No date): HIV Sentinel Surveillance - 2004.

http://www.aidskenya.org/SurveillanceReport.pdf [Cited 2007/3/31].
Ngigi, M.M. (2007): AIDS and the city: Exploring the spatial characteristics of HIV/AIDS pandemic in Nairobi, Kenya. Geogr. Rev. Jpn., (in press).

Oppong, J.R. (1998): A vulnerability interpretation of the geography of HIV/AIDS in Ghana, 19861995. Prof. Geogr., 50, 437-448.

Oppong, J.R. and Agyei-Mensah, S. (2004): HIV/ AIDS in West Africa: The case of Senegal, Ghana, and Nigeria. in HIV and AIDS in Africa: Beyond Epidemiology edited by Kalipeni, E., Craddock, S., Oppong, J.R. and Ghosh, J., Blackwell, 70-88.

UNAIDS (2006): AIDS Epidemic Update 2006. UNAIDS/WHO.

UNAIDS/WHO/UNICEF (2002): Epidemiological Fact Sheet on HIV, AIDS and STIs September 2002. UNAIDS.

Van de Perre, P. (1995): The epidemiology of HIV infection and AIDS in Africa. Trends Microbiol., 3, 217-222.

Whiteside, A. (2002): Poverty and HIV/AIDS in Africa. Third World Q., 23, 313-332.

Zulu, E.M., Dodoo, F.N. and Ezeh, A.C. (2004): Urbanization, poverty, and sex: Roots of risky sexual behaviors in slum settlements in Nairobi, Kenya. in HIV and AIDS in Africa: Beyond Epidemiology edited by Kalipeni, E., Craddock, S., Oppong, J.R. and Ghosh, J., Blackwell, 167-174.

(Received 15 January, 2007; Accepted 9 April, 2007) 


\title{
都市化，貧困および文化からみた \\ ケニアにおける HIV/AIDS 伝染の空間的パターン
}

\author{
ギギ モセス ムリミ*
}

2003 年にケニアでは 130 万人以上が HIV/AIDS に感染するとともに 15 万人上が死亡しており, HIV/AIDS の伝染は国全体に大きな社会的インパ クトを与え続けている。監視疫学のデータによる と, 1990 年以降 HIV/AIDS の伝染は地域的に異 なっており，それはHIV/AIDS 伝染と国全体の 疫病拡散およびその強度に関する要因との地域 格差として現れている。国家的レベルでみると都 市部でより感染率が高くなっているが, 県別の感 染率と都市人口率との相関は有意ではない。しか しながら, 出稼ぎ労働者が故郷と都市部を定期的 に移動することにより, 農村部および都市部の両 方で一定の感染率が保たれている。感染率の高い Nyanza 県では貧困の度合いが高く, 貧困が HIV/ AIDS 伝染の一因であると言える。しかしながら
同じような貧困の度合いを示す North Eastern 県 では感染率が低く, HIV/AIDS 伝染の空間的なダ イナミクスに関する要因は貧困の度合いだけでは ない。また感染率と民族構成との相関をみると, ニロート族のエスニックグループと強い正の相関 関係がある一方で, 中部バントゥ族や西ハム族, 東ハム族のグループとは負の相関関係があった。 このことから，伝染の空間的パターンには別の要 因，とくに文化的慣行が影響しているのではない かと推定できる。さらに, HIV/AIDS 感染を緩和 するために HIV/AIDS の監視システムをより地域 的レベルへ拡大することで, HIV/AIDS の空間的 パターンを規定する要因を調査する際に必要な情 報提供が期待できる。

キーワード : HIV/AIDS, 伝染病, 都市化, 貧困, 文化, ケニア

* 筑波大学大学院生命環境科学研究科 